\title{
Clinical reinvestigation and linkage analysis in the family with Episkopi blindness (Norrie disease)
}

\author{
G Wolff, A Mayerová, T F Wienker, P Atalianis, P Ioannou, M Warburg
}

\begin{abstract}
We present the results of a clinical and genetic reinvestigation of the Cypriot family affected by an $X$ chromosomally inherited eye disease originally published by Taylor et al, who coined the term Episkopi blindness. The pedigree was extended to 160 members, including 16 affected males out of $\mathbf{4 8}$ males at risk for the disease, most of whom were seen by one of us (PA). Affected males are blind with no associated symptoms and apparently are not mentally retarded. Thirtynine family members agreed to blood sampling for genetic investigations. RFLP analysis was performed using probes from the region known to be deleted in some Norrie patients and polymorphic markers (DXS77, DXS7, $M A O A, D X S 255$ ) from the proximal short arm of the $X$ chromosome. There was no deletion for any of the probes in the affected males. Linkage analysis yielded positive lod scores for all informative markers $(\hat{\mathbf{Z}}(D X S 255, \theta=0)=6.54$, $\hat{\mathbf{Z}}(M A O A, \theta=0)=2 \cdot 23, \hat{\mathbf{Z}}(D X S 7, \theta=0)$ $=2 \cdot 13)$. Thus, the conclusion that Episkopi blindness and Norrie disease (NDP, MIM *310600) are the same entity based on clinical evidence is now reinforced by gene mapping.

( $\mathcal{F}$ Med Genet 1992;29:816-9)
\end{abstract}

Norrie disease (ND) is an $\mathrm{X}$ linked recessive disorder characterised by blindness caused by the early development of retinal dysplasia, vascular proliferation (pseudoglioma), and ocular phthisis ${ }^{1}$ (MIM *310600). Over 300 cases have been described, about one third of which have additional symptoms such as sensorineural hearing loss, mental retardation, or psychotic behaviour. ${ }^{2-4}$ Close linkage has been shown between the disease locus (NDP) and $D X S 7$ at $\mathrm{Xp} 11.3$ defined by probe L1.28 bringing the compiled lod score for linkage between NDP and DXS7 to 6.51 at $\theta=0.00$. $^{8}$ Recombination events between these two loci have been reported by Ngo et al..$^{910}$

Several patients with Norrie disease have been reported who carry microdeletions encompassing $D X S 7 . .^{11-14}$ In the patient of Donnai et $a l,{ }^{13}$ the deletion included DXS228 defined by probe $1 \mathrm{aA} 6$. In the patients of $\mathrm{Gal}$ et $a l^{12}$ and de la Chapelle et al, ${ }^{11}$ the $M A O A$ and $M A O B$ genes were also shown to be deleted. ${ }^{1516}$ Sims et $a l^{17}$ reported another deletion patient who uniquely retained the $D S X 7$ locus while being deleted for $M A O A$ and $M A O B$. In addition to the ophthalmic features the clinical picture in the deletion cases comprised one or more symptoms such as severe mental retardation, hypotonia, hyperreflexia, microcephaly, cryptorchidism, and failure to thrive. ${ }^{1315}$

Taylor et $a l^{18}$ reported a six generation Greek Cypriot family with an apparently X linked blindness living in Episkopi in Cyprus, the disease therefore being popularly known as Episkopi blindness. This condition was thought to be another example of Norrie disease on clinical and genetic grounds by Warburg. ${ }^{1}$ The family was restudied clinically by Merin et al $^{19}$ in 1972.

We performed a clinical reinvestigation of the family and linkage analysis with DNA markers from the short arm of the X chromosome to test the identity of Episkopi blindness and Norrie disease.

\section{Materials and methods}

FAMILY AND PATIENTS

The family is personally known to one of us (PA). This allowed us to take the family history and to extend the pedigree to $160 \mathrm{mem}$ bers including 16 affected males out of 48 males at risk (fig 1). Of the living affected males and obligate female carriers all but one each (VI.47, V.17) were seen. Unfortunately, neither the male patients nor the female obligate carriers were willing to see an ophthalmologist for thorough ophthalmoscopic examination. Thirty-nine family members (including one husband of a potentially heterozygous woman) agreed to blood sampling for genetic analysis.

\section{PROBES}

The following probes were used in this study: L1.28 (TaqI) defining DXS7, ${ }^{20}$ pX59 (EcoRV) defining $D X S 77,{ }^{21} \mathrm{M} 27 \beta$ (EcoRI) defining $D X S 255,22$ and MAO-A (EcoRV) defining $M A O A{ }^{23}$

\section{METHODS}

Chromosomal DNA from peripheral blood cells were isolated using standard methods. After digestion with restriction enzymes according to the manufacturer's specifications and separation on $0.8 \%$ agarose gels, the DNA was blotted onto Hybond $\mathrm{N}+$ (Amersham) membranes and hybridised to a probe radio- 


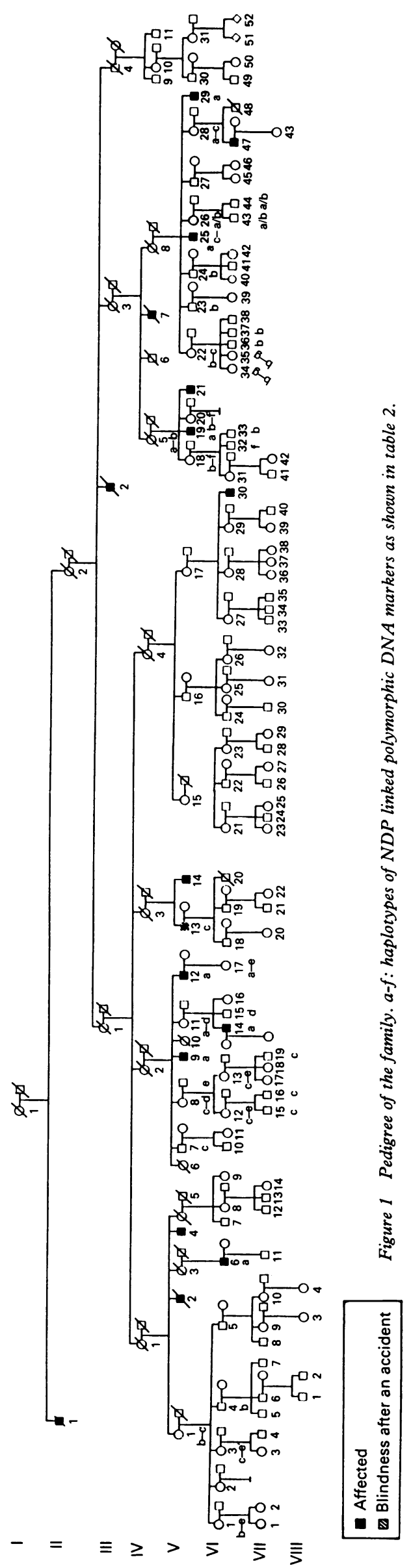

actively oligolabelled by the method of Feinberg and Vogelstein. ${ }^{24}$ Prehybridisation and hybridisation were performed at $65^{\circ} \mathrm{C}$ in $0.5 \mathrm{~mol} / \mathrm{l}$ sodium phosphate, $0.001 \mathrm{~mol} / \mathrm{l}$ EDTA, and $7 \%$ sodium dodecyl sulphate. Blots were autoradiographed after being washed with $0.02 \mathrm{~mol} / 1$ sodium phosphate and $1 \%$ sodium dodecyl sulphate at $65^{\circ} \mathrm{C}$.

Lod scores were calculated using the LIPED program, ${ }^{25}$ and multipoint linkage analysis was performed using the LINKMAP program, version $5 \cdot 10$, kindly provided by $\mathrm{J}$ Ott (fig 2).

\section{Results and discussion}

The pedigree, compared with that published by Taylor et al, ${ }^{18}$ could be extended by one generation and 66 family members (fig 1).

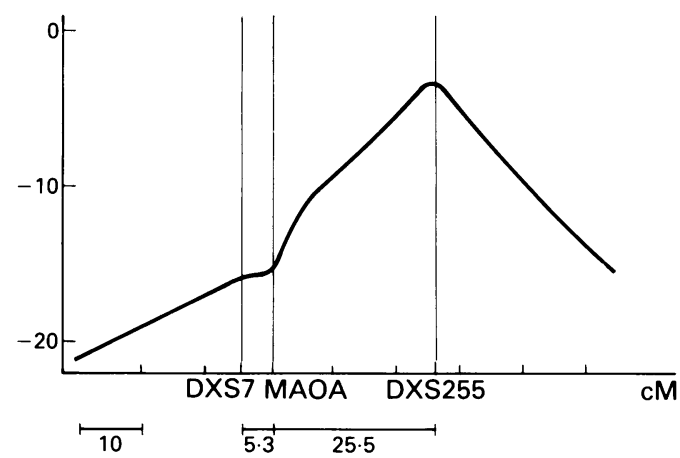

Figure 2 Multipoint linkage analysis using the

LINKMAP program (version 5.1, provided by $\mathcal{F}$ Ott 1991). The vertical axis gives the location scores. ${ }^{26}$ Note the scale factor and offset. The horizontal axis is related to the marker map according to Mahtani et al. ${ }^{27}$ Locus DXS77 is not shown, because there is no significant contribution (table 3). The unusual shape of the location score curve results from the absence of recombination events in the Episkopi pedigree. Absence of interference is assumed and hence Haldane's mapping function is used.

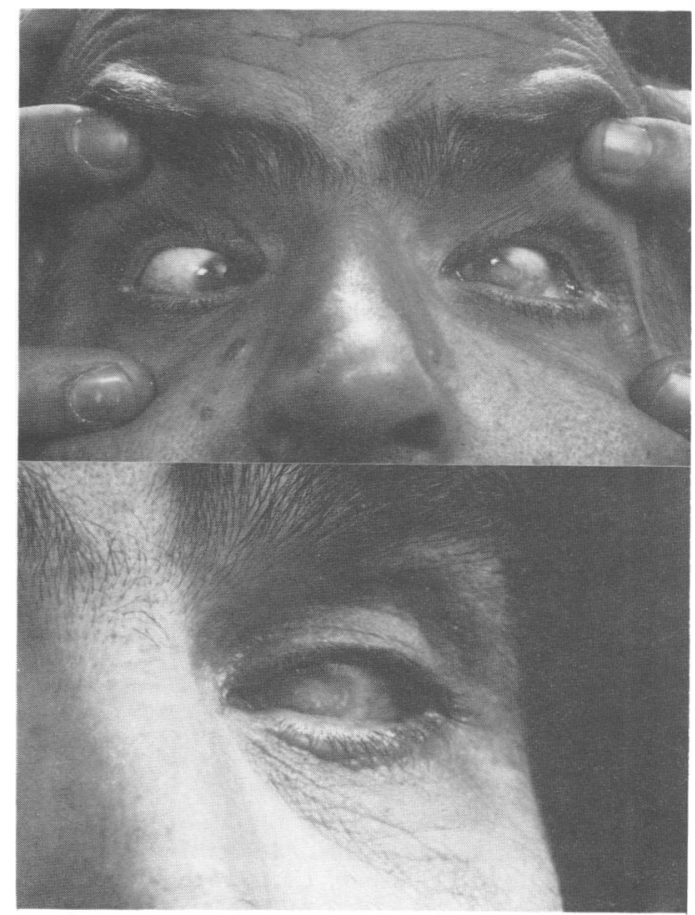

Figure 3 Clinical features of V.9 at the age of 55 years. 
Ophthalmic symptoms in the affected are shown in table 1. All suffer from congenital blindness apart from three, who had some vision or light perception up to 3,7 , and 13 years of age. V.13 is blind after an accident with an insecticide spray at the age of 55 . The clinical features of one of the patients (V.9) is shown in fig 3. A CT scan in another affected subject, who had some vision in the right eye and perception of light in the left up to 7 years of age, is shown in fig 4 . This clearly shows the variability of expression of the gene defect. At the time of our investigation none of the living patients who were seen by us had mental or hearing defects, and none had any of the additional symptoms frequently observed in Norrie disease, especially in patients with microdeletions. Accordingly we did not find a microdeletion with the probes X.59, L1.28, or MAO-A which are known to detect deletions in some of the patients with Norrie disease. A DNA probe $500 \mathrm{~kb}$ proximal to

Table 1 Clinical data of 11 patients.

\begin{tabular}{|c|c|c|c|c|c|c|c|c|}
\hline $\begin{array}{l}\text { Pedigree } \\
\text { No }\end{array}$ & $\begin{array}{l}\text { Age at the } \\
\text { time of this } \\
\text { study }\end{array}$ & Side & Small eye & $\begin{array}{l}\text { Diffuse } \\
\text { corneal } \\
\text { opacity }\end{array}$ & $\begin{array}{l}\text { Band shaped } \\
\text { corneal } \\
\text { opacity }\end{array}$ & Cataract & $\begin{array}{l}\text { Retrolental } \\
\text { opacity }\end{array}$ & $\begin{array}{c}\text { Amaurosis } \\
(\mathrm{V}=\text { vision, } \\
\mathrm{PL}=\text { perception } \\
\text { of light })\end{array}$ \\
\hline \multirow[t]{2}{*}{ V.4 } & 72 & $R$ & - & + & + & & & + \\
\hline & & L & - & + & + & & & + \\
\hline V.9 & 55 & $\bar{R}$ & + & & + & & & + \\
\hline \multirow{2}{*}{ V.12 } & 54 & $\begin{array}{l}\mathrm{L} \\
\mathrm{R}\end{array}$ & + & $\begin{array}{l}+ \\
+\end{array}$ & $\overline{+}$ & & & $\mathrm{PL}^{+}(13 \mathrm{y})$ \\
\hline & & $\mathbf{L}$ & + & + & + & & & V $(9 y)$ \\
\hline \multirow{2}{*}{ V.19 } & 45 & $\mathbf{R}$ & + & + & + & & & + \\
\hline & & L & + & + & + & & & + \\
\hline \multirow{2}{*}{ V.21 } & 41 & $\mathbf{R}$ & - & - & - & + & & + \\
\hline & & L & - & - & - & & + & PL (6y) \\
\hline \multirow[t]{2}{*}{ V.25 } & 63 & $\mathrm{R}$ & + & + & + & & & + \\
\hline & & L & + & + & + & & & + \\
\hline \multirow[t]{2}{*}{ V.29 } & 53 & $\mathbf{R}$ & + & + & + & & & + \\
\hline & & $\mathrm{L}$ & + & + & + & & & + \\
\hline \multirow[t]{2}{*}{ VI.6 } & 53 & $\mathrm{R}$ & - & + & + & & & + \\
\hline & & $\mathrm{L}$ & - & + & & & & + \\
\hline \multirow[t]{2}{*}{ VI.14 } & 35 & $\bar{R}$ & + & + & - & & $+^{*}$ & $V(7 y)$ \\
\hline & & L & + & + & - & & $+^{*}$ & PL (7y) \\
\hline \multirow[t]{2}{*}{ VI.30 } & 41 & $\mathbf{R}$ & + & + & + & & & + \\
\hline & & L & + & + & + & & & + \\
\hline \multirow{2}{*}{ VI.47† } & 42 & $\mathbf{R}$ & + & + & - & & & + \\
\hline & & L & - & - & - & + & & + \\
\hline
\end{tabular}

*Seen on ocular scans.

†Information quoted from Taylor $e t$ al. ${ }^{18}$

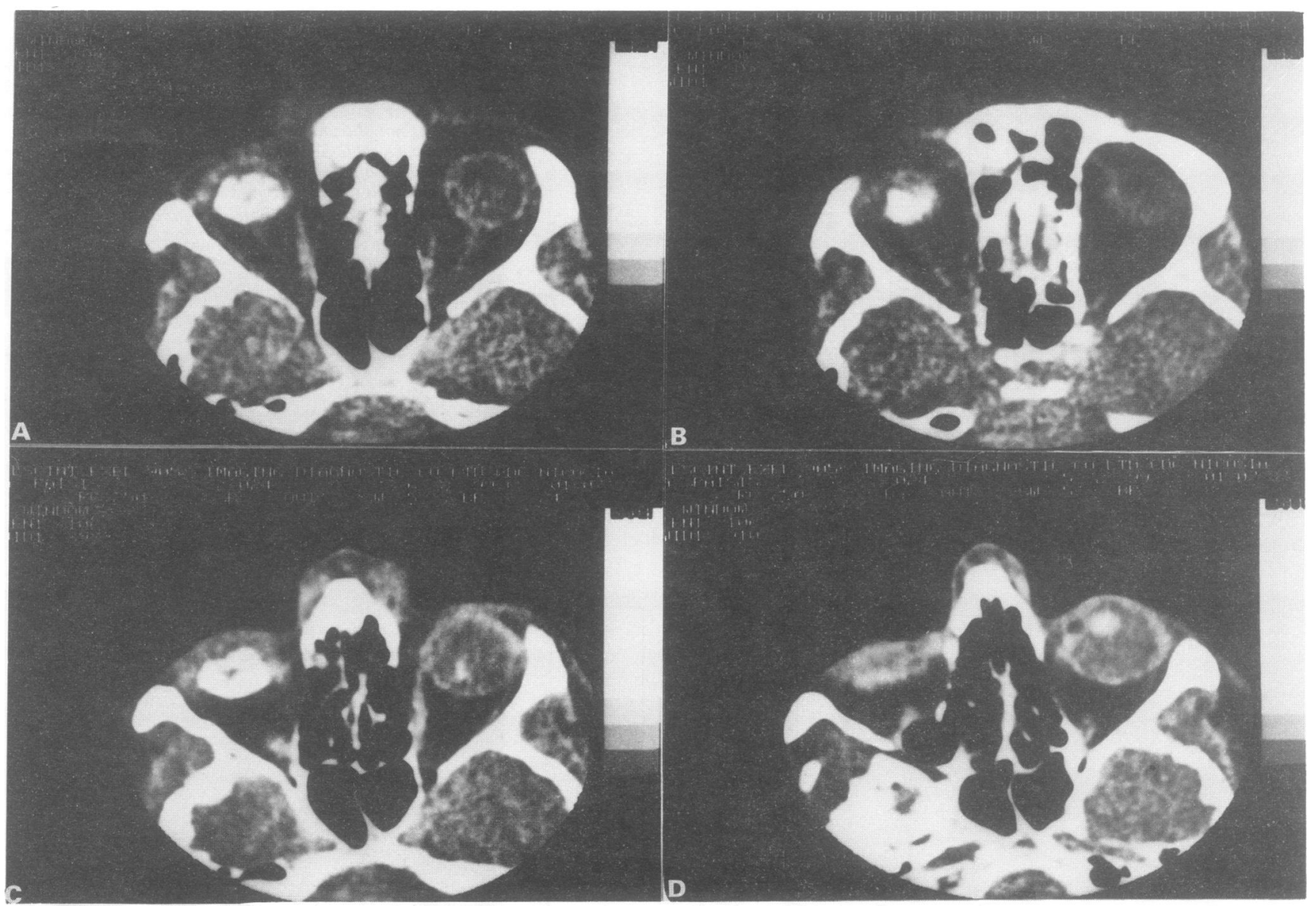

Figure 4 Cranial CT scan of VI.14 at the age of 35 years. He had some vision on the right up to 7 years and perception of light by the age of 7 on the left. Note on the left a small osseous orbit, a small globe with squamous calcification in a ring-like configuration, and a central, non-calcified area $(A)$, and diminution of the optic nerve $(B)$. On the right, spotty calcifications in the posterior segment of the eye ( $C$ ) and a slight hyperdensity in the medial part of the lens (D) can be seen. 
Table 2 Marker haplotypes for four NDP linked loci segregating in the family.

\begin{tabular}{|c|c|c|c|c|c|c|c|c|c|}
\hline \multirow[b]{2}{*}{ Locus } & \multirow[b]{2}{*}{ Probe } & \multirow[b]{2}{*}{ Enzyme } & \multicolumn{7}{|c|}{ Haplotypes } \\
\hline & & & a & b & c & d & e & f & g \\
\hline $\begin{array}{l}D X S 77 \\
D X S 7 \\
M A O A \\
D X S 255\end{array}$ & $\begin{array}{l}\text { X59 } \\
\text { L1.28 } \\
\text { MAO-A } \\
\text { M27 } \beta\end{array}$ & $\begin{array}{l}\text { EcoRV } \\
\text { TaqI } \\
\text { EcoRV } \\
\text { Eco RI }\end{array}$ & $\begin{array}{l}1 \\
1 \\
1 \\
1\end{array}$ & $\begin{array}{l}1 \\
2 \\
2 \\
2\end{array}$ & $\begin{array}{l}1 \\
1 \\
1 \\
3\end{array}$ & $\begin{array}{l}1 \\
1 \\
1 \\
4\end{array}$ & $\begin{array}{l}1 \\
1 \\
1 \\
2\end{array}$ & $\begin{array}{l}1 \\
2 \\
2 \\
4\end{array}$ & $\begin{array}{l}2 \\
1 \\
1 \\
3\end{array}$ \\
\hline
\end{tabular}

Table 3 Lod scores of main locus and marker data, calculated using the LIPED program.

\begin{tabular}{|c|c|c|c|c|c|c|c|c|c|c|}
\hline \multirow[b]{2}{*}{ Locus } & \multirow[b]{2}{*}{$v$} & \multirow[b]{2}{*}{ Locus } & \multicolumn{6}{|c|}{$\theta$} & \multirow[t]{2}{*}{$\hat{\theta}$} & \multirow[t]{2}{*}{$Z(\hat{\theta})$} \\
\hline & & & 0.00 & 0.05 & $0 \cdot 10$ & $0 \cdot 20$ & 0.30 & 0.40 & & \\
\hline$D X S 255$ & $v$ & $\begin{array}{l}D X S 7 \\
D X S 77 \\
M A O A \\
D X S 255 \\
M A O A \\
D X S 255 \\
M A O A\end{array}$ & $\begin{array}{l}2 \cdot 13 \\
0.04 \\
2 \cdot 23 \\
6.54 \\
5.05 \\
-\infty \\
-\infty\end{array}$ & $\begin{array}{l}1.97 \\
0.03 \\
2.05 \\
5.97 \\
4.61 \\
3.05 \\
3.13\end{array}$ & $\begin{array}{l}1.79 \\
0.02 \\
1.86 \\
5.37 \\
4.15 \\
2.96 \\
3.03\end{array}$ & $\begin{array}{l}1.39 \\
0.01 \\
1.44 \\
4 \cdot 11 \\
3 \cdot 19 \\
2.43 \\
2.48\end{array}$ & $\begin{array}{l}0.95 \\
0.00 \\
0.98 \\
2.76 \\
2.14 \\
1.70 \\
1.74\end{array}$ & $\begin{array}{l}0.45 \\
0.00 \\
0.47 \\
1.36 \\
1.01 \\
0.84 \\
0.87\end{array}$ & $\begin{array}{l}0.00 \\
0.00 \\
0.00 \\
0.00 \\
0.00 \\
0.057 \\
0.056\end{array}$ & $\begin{array}{l}2.129 \\
0.041 \\
2.233 \\
6.537 \\
5.049 \\
3.053 \\
3.135\end{array}$ \\
\hline
\end{tabular}

L1.28 also failed to detect a deletion in one of the affected males ( $T$ Meitinger, personal communication).

Results of DNA haplotyping are shown in fig 1 and table 2 . As can be seen the phenotype 'Episkopi blindness' cosegregates with the ' $a$ ' haplotype. There is only one crossover between $D X S 255$ and $M A O A$ in V.26, indicated as a/b haplotype. Linkage analysis yielded positive lod scores for all markers segregating in an informative fashion (table 3). Thus, the identity of Episkopi blindness and Norrie disease is supported by gene mapping. DXS255 (probe M27 $\beta$ ) gives the highest lod score (6.54 at $\theta=0.00$ ) only because it is the most informative marker and there are no recombinations between NDP and any of the markers used. Clearly, the Norrie disease locus must be located in close proximity to the $M A O A$ locus. ${ }^{28}$

Our result will enable effective genetic counselling and heterozygote detection in the family. Further analysis with other probes located in the region of interest and finally mutation analysis of the as yet unidentified gene itself will prove the hypothesis that in this family with Episkopi blindness we are dealing with a mutation within the Norrie disease gene.

We thank Professor Schumacher from the Radiologische Universitätsklinik Freiburg, Sektion Neuroradiologie, for the interpretation of the CT scans, and Mrs Wurich for excellent secretarial assistance.

1 Warburg $M$. Norrie's disease: a new hereditary bilateral pseudotumor of the retina. Acta Ophthalmol (Copenh) 1961;39:757-72.

2 Warburg $M$. Norrie's disease, a congenital progressive oculo-acustico-cerebral degeneration. Acta Ophthalmol (Copenh) 1966;89(suppl):1-147.

3 Parving A, Warburg M. Audiological findings in Norrie's disease. Audiology 1977;16:124-31. 4 Johnston SS, Hanna JE, Nevin NC, Bryars JH. Norrie's

5 Gal A, Stolzenberger C, Wienker T, et al. Norrie's disease: close linkage with genetic markers from the proximal short arm of the X chromosome. Clin Genet 1985;27:2823 .

6 Bleeker-Wagemakers LM, Friedrich U, Gal A, Wienker TF, Warburg M, Ropers HH. Close linkage between imal short arm, and the centromere of the $\mathrm{X}$ chromosome.
introm the proxHum Genet 1985;71:211-4.

7 Kivlin JD, Sanborn GE, Wrigth E, Cannon L, Carey J. Further linkage data on Norrie disease. $A m \mathcal{F}$ Med Genet 1987;26:733-6.
$8 \mathrm{Gal}$ A, Uhlhaas S, Glaser D, Grimm T. Prenatal exclusion of Norrie disease with flanking DNA markers. $A m \mathcal{F}$ Med Genet 1988;31:449-53.

9 Ngo J, Spence MA, Cortessis V, Bateman JB, Sparkes RS. Duplicate report crossing over in Norrie disease family. Am F Med Genet 1989;33:286.

10 Ngo JT, Spence MA, Cortessis V, Sparkes RS, Bateman JB. Recombinational event between Norrie disease and DXS7 loci. Clin Genet 1988;34:43-7.

11 de la Chapelle A, Sankila EM, Lindlof M, Aula P, Norio R. Norrie disease caused by a gene deletion allowing carrier detection and prenatal diagnosis. Clin Genet 1985;28:31720.

12 Gal A, Wieringa B, Smeets DFCM, Bleeker-Wagemakers L, Ropers HH. Submicroscopic interstitial deletion of the dominated by Norrie disease. Cytogenet Cell Genet dominated by

13 Donnai D, Mountford RC, Read AP. Norrie disease resulting from a gene deletion: clinical features and DNA ing from a gene deletion: clinical

14 Zhu D, Antonarakis SE, Schmeckpeper BJ, Diergaarde PJ, Greb AE, Maumenee IH. Microdeletion in the X-chromosome and prenatal diagnosis in a family with Norrie disease. Am F Med Genet 1989;33:485-8.

15 Sims KB, de la Chapelle A, Norio R, et al. Monoamine oxidase deficiency in males with an $\mathrm{X}$ chromosome deletion. Neuron 1989;2:1069-76.

16 Lan NC, Heinzmann C, Gal A, et al. Human monoamine oxidase $\mathrm{A}$ and $\mathrm{B}$ genes map to $\mathrm{Xp} 11.23$ and are deleted in a patient with Norrie disease. Genomics 1989;4:552-9.

17 Sims K, Benson G, Hotannisligil G, et al. Further genetic and physical mapping of the Norrie disease locus on Xp11.3. Am ₹ Hum Genet 1991;49(suppl):389.

18 Taylor PJ, Coates T, Newhouse ML. Episkopi blindness: hereditary blindness in a Greek Cypriot family. $\mathrm{Br} \mathfrak{f}$ Ophthalmol 1959;43:340-4.

19 Merin S, Lapithin AG, Horovitz D, Michaelson IC. Childhood blindness in Cyprus. Am $\mathrm{f}$ Ophthalmol 1972;74:538-42.

20 Wieacker P, Davies KE, Cooke HJ, et al. Towards a complete linkage map of the human $\mathrm{X}$ chromosome; regional assignment of 16 cloned single-copy DNA seregional assignment of 16 cloned single-copy DNA se-
quences employing a panel of somatic cell hybrids. $A m \mathfrak{f}$ quences employing a panel of

21 Willard HE, Schmeckpeper BJ, Smith KD, Goss SJ. High resolution regional mapping of human $\mathrm{X}$-chromosome by radiation induced segregation analysis of $X$ linked DNA probes. Cytogenet Cell Genet 1983;37:609-10.

22 Fraser NJ, Boyd Y, Brownlee GG, Craig IW. Multi-allelic RFLP for M27 $\beta$, an anonymous single copy genomic clone at Xp11.3-Xcen [HGM9 provisional no. DXS255]. Nucleic Acids Res 1987;15:9616.

23 Hsu YPP, Weyler W, Chen S, et al. Structural features of human monoamine oxidase A elucidated from cDNA and peptide features. $\mathcal{I}$ Neurochem 1988;51:1321-4.

24 Feinberg AP, Vogelstein B. A technique for radiolabeling DNA restriction endonuclease fragments to high specific activity. Anal Biochem 1984;132:6-13.

$25 \mathrm{Ott} \mathrm{J}$. A computer program for linkage analysis of general human pedigrees. Am 7 Hum Genet 1976;28:528-9.

26 Lathrop GM, Lalouel JM, Julier C, Ott J. Multilocus linkage analysis in humans: detection of linkage and estimation of recombination. Am $\mathcal{f}$ Hum Genet 1985;37:482-98.

27 Mahtani MM, Lafrenière RG, Kruse TA, Willard HF. An 18-locus linkage map of the pericentric region of the 18-locus linkage map of the pericentric region of the
human $\mathrm{X}$ chromosome: genetic framework for mapping human X chromosome: genetic framework for

28 Collins FA, Murphy DL, Reiss AL, et al. Clinical, biochemical, and neuropsychiatric evaluation of a patient with a contiguous gene syndrome due to a microdeletion Wp11.3 including the Norrie disease locus and monoamine oxidase (MAOA and MAOB) genes. Am $f$ Med Genet 1992;42:127-34. 